\title{
Erratum to: Shift in microbial group during remediation by enhanced natural attenuation (RENA) of a crude oil-impacted soil: a case study of Ikarama Community, Bayelsa, Nigeria
}

Chioma Blaise Chikere ${ }^{1} \cdot$ Christopher Chibueze Azubuike $^{1} \cdot$ Evans Miebaka Fubara $^{1}$

Published online: 5 July 2017

(C) Springer-Verlag GmbH Germany 2017

Erratum to: 3 Biotech (2017) 7:152

DOI 10.1007/s13205-017-0782-x

In the original article, the author name Evan Miebaka Fubara was published incorrectly. The correct author name is given below:

Evans Miebaka Fubara.

The online version of the original article can be found under doi:10.1007/s13205-017-0782-x.

Chioma Blaise Chikere

chioma.chikere@uniport.edu.ng

1 Department of Microbiology, Faculty of Science, University of Port Harcourt, East-West Road, PMB 5323, Choba,

Port Harcourt 500004, Rivers State, Nigeria 